MATEC Web of Conferences 6, 06001 (2013)

DOI: $10.1051 /$ matecconf/20130606001

(C) Owned by the authors, published by EDP Sciences, 2013

\title{
Fire safety assessment and upgrading of existing traffic tunnels
}

\author{
U. Diederichs ${ }^{1}$, L. Bodnarova ${ }^{2}$ and V. Petranek ${ }^{2}$ \\ ${ }^{1}$ Universität Rostock, Institute of Civil Engineering, Rostock, Germany \\ 2 Brno University of Technology, Faculty of Civil Engineering, Brno, Czech Republic
}

\begin{abstract}
Many traffic tunnels in the European Union need records of their conservation and safety status, including fire performance. Besides other countries the German road transport authorities plan to enhance the safety of their tunnels. As an example, the results of investigations performed with a two-tube tunnel in Northern Germany, which has been examined to assess fire safety, is reported. It turned out, that the older tube, which got fire protection boards on the ceilings and the wall crowns, fully fits the demands according to the current rules. The later tube needs an upgrading to avoid catastrophic impairment of air and car traffic in the vicinity of the tunnels. For the retrofitting a number of protection materials are in the market. The execution of the measure requires smart planning as to reach the strived goal.
\end{abstract}

\section{INTRODUCTION}

A lot of the tunnels in European Union now reaching an age, in which repairs and safety upgrades are needed which means, that their conservation and safety status must be recorded and evaluated. E.g., the German State, owner of respective buildings, plans to enhance their safety according to the state-of-theart. This comprises the fire safety upgrading due to the latest version of the RABT (guidelines for the equipment and operation of tunnels) [1] or ZTV-ING [2] (supplementary technical contractual teams for engineering structure, like bridges, tunnels etc.), too. But, also other countries have increased their efforts in research, and developed regulations and guidelines to improve the fire safety of their traffic systems [3-7].

In the following, the determination of the basics for the assessment of the fire safety of tunnels in a large city of Northern Germany is introduced. It encompasses, the visual inspection of the building elements as well as drilling and investigation of concrete cores and - if applicable - inspection of the fire protection boards on the ceilings and side wall crowns.

Based on the results of the above mentioned investigations fire behaviour of the bearing elements is evaluated. Subsequently the measures for the required upgrading are outlined and compiled in the following.

\section{CONSTRUCTION AND LOCATION OF THE TUNNEL}

The considered traffic tunnel consists of two rectangular tubes. It is located below the runway of the airport and connects two major four-lane streets of the city. The two tubes of the tunnel are around $400 \mathrm{~m}$ long. Each consists of 40 single blocks, separated by joints. The north wall of the south tube, which was erected in 1963 , has a thickness of $1.30 \mathrm{~m}$. The south wall is $0.50 \mathrm{~m}$ thick and separates the pedestrian tunnel from the car traffic (Fig. 1). The reinforced concrete ceiling slab is 1.17 to $1.35 \mathrm{~m}$

This is an Open Access article distributed under the terms of the Creative Commons Attribution License 2.0, which permits unrestricted use, distribution, and reproduction in any medium, provided the original work is properly cited. 


\section{MATEC Web of Conferences}

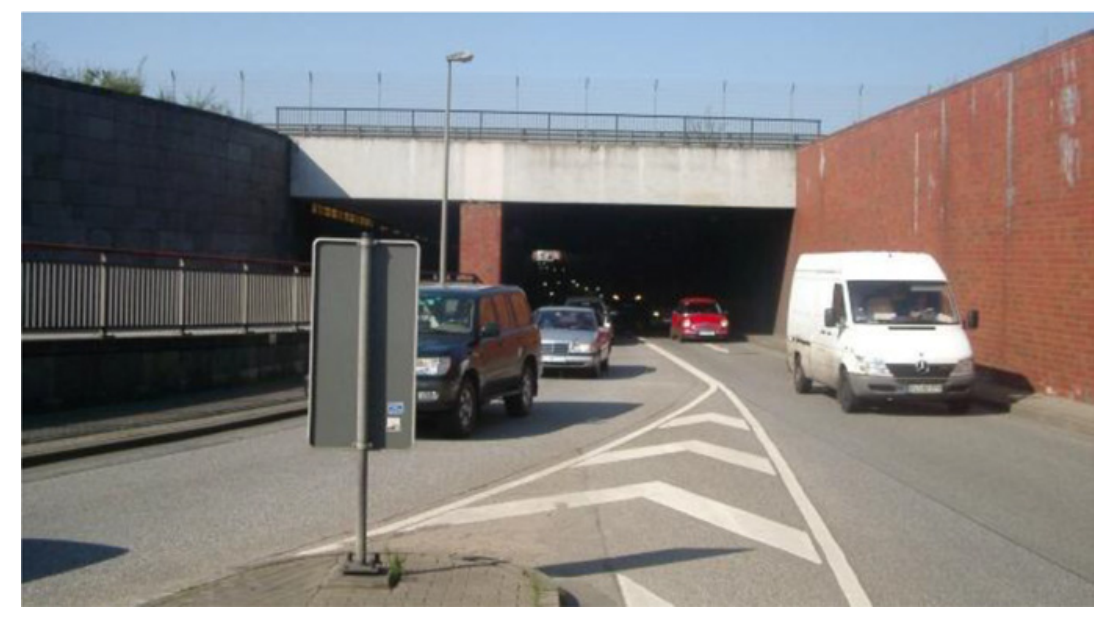

Figure 1. View of the east exit of the southern tube of the traffic tunnel.

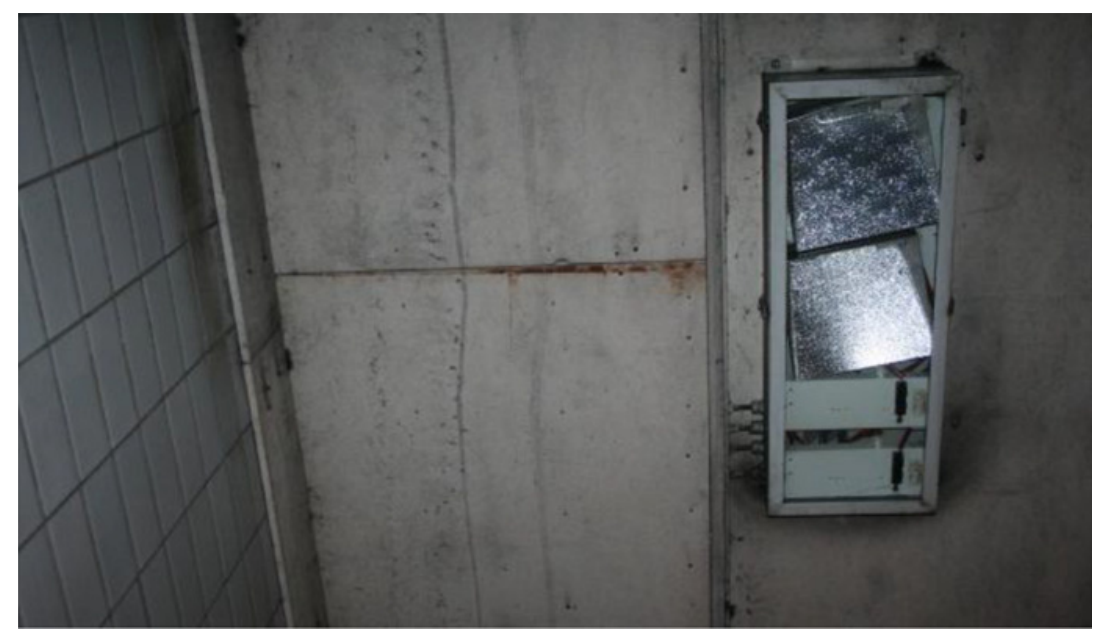

Figure 2. Ceiling and side wall of the southern tube with fire protection boards on the ceiling and the wall crown and tiles on the lower part of the wall.

high. The ceiling and the upper ends of the walls are protected by a $20 \mathrm{~mm}$ thick fire protection board made with calcium silicate (Fig. 2).

The single blocks of the northern tube, erected in 1997, have a wall thickness of $1.235 \mathrm{~m}$. The height of the ceiling slabs reaches from 1.25 to $1.375 \mathrm{~m}$. The ceiling as well as the walls is executed as faced concrete. In case of accident their surfaces would be directly exposed to fire.

\section{PROPERTIES OF THE CONSTRUCTIONAL CONCRETE}

\subsection{Specimens}

To get knowledge concerning the actual properties of the concrete in the construction elements a few representative cores have been drilled out of the ceilings and walls by means of an electro drilling machine equipped with a diamond crown. Also, a part of the silicate boards has been removed from the ceiling for further inspections. 


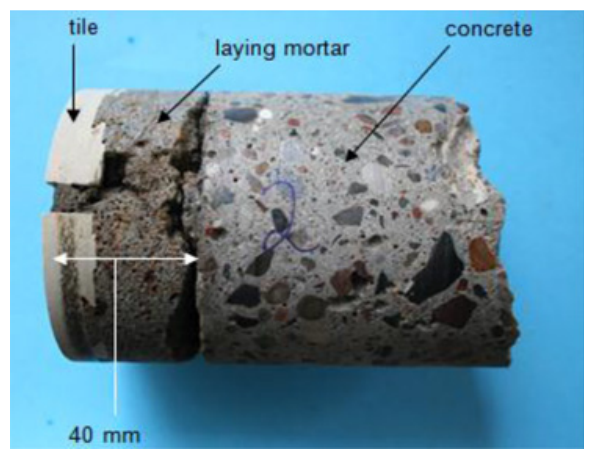

Figure 3. Shell surface of core 2, which has been taken out of the lower side wall of the southern tube of the tunnel.

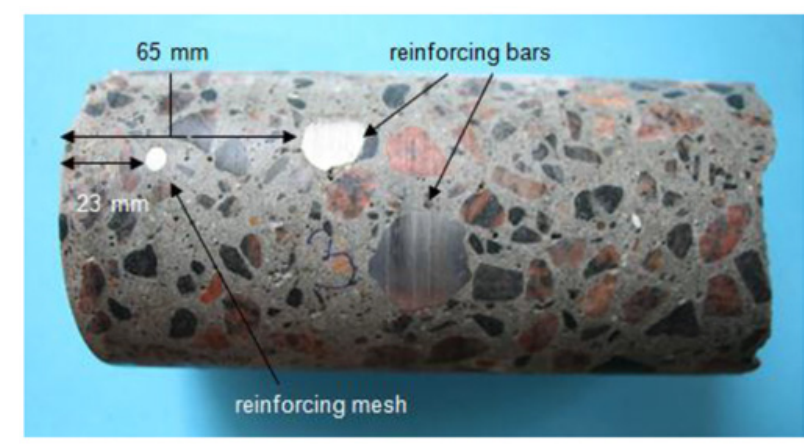

Figure 4. Shell surface of core 3, which has been taken out of the ceiling of the northern tube. On the left hand side the anti-spalling mesh is visible, in the middle the load bearing reinforcement.

\subsection{Visual inspection of the concrete cores}

The visual inspection of the cores has revealed the following:

The concrete of the southern tube (core K1 and K2, see Fig. 3) and the concrete of the northern tube (core K3 and K4, see Fig. 4) indicate a good grading, are well-structured and contain a sufficient amount of fines required, as to achieve a dense concrete with high strength (Fig. 3 and Fig. 4).

The concrete taken out of the walls contains few coarse pores (in particular in the regions near the surface) caused by air bubbles, which have not been expelled during compaction (Fig. 3 and Fig. 4)).

The coarse aggregates of the concrete of the southern tunnel consist of crushed granite and gravel from the northern part of Germany (Fig. 3). The coarse aggregates of the concrete from the northern tunnel consist almost entirely of granite (Fig. 4). As a binder the ordinary Portland cement was used with both concretes. The outside faces of the cores K1, K3 and K4 still had the sharp contours of the original structure of the mould skin. Weathering or sanding of the surfaces has not occurred. In the extraction region of the core K2 (southern wall of the tunnel), the surface of the wall has been tiled. When the core sample was taken the laying mortar broke away from the concrete surface (Fig. 3). The type of fracture was a cohesive failure in the surface of the mortar layer next to the concrete (Fig. 3).

\subsection{Strength, raw density and carbonation depth of concrete}

To determine the strength and the raw density the cores were cut, ground plan parallel and dried at ambient air in the laboratory. Also carbonation depths have been determined by spraying phenolphthalein solution on fresh fractured surfaces as to get an idea concerning the density of the concrete. The respective results are given in the following Table 1.

The characteristic compressive strength value have been estimated according to EN 13791

$$
\begin{aligned}
& \mathrm{f}_{\mathrm{ck}, \text { is,south }}=31.7 \mathrm{~N} / \mathrm{mm}^{2} \text { for the south tube (built 1963) } \\
& \mathrm{f}_{\text {ck,is,north }}=52.7 \mathrm{~N} / \mathrm{mm}^{2} \text { for the north tube (built 1997). }
\end{aligned}
$$

The concrete of the older south tube can be classified into C30/37, which is a good quality normal strength concrete. The concrete of the newer north tube reaches strength class C50/60 and approaches almost class C55/67, which is a high strength concrete.

The outer front face of the specimen K2 was covered with tiles, thus there is no carbonation. In consideration of the different durations of exposure to air (K1 about 50 years and $\mathrm{K} 3$ and $\mathrm{K} 4$ about 15 years) the carbonation depth is nearly the same. Due to the high $\mathrm{CO}_{2}$-concentration in the tunnel it exceeds a little bit the values expected for a concrete of a similar strength class [8]. 


\section{MATEC Web of Conferences}

Table 1. Compressive strength, raw density and carbonation depth of the concrete cores.

\begin{tabular}{|c|c|c|c|c|}
\hline Specimen & Extracted from & $\begin{array}{c}\text { Raw density } \\
{\left[\mathbf{k g} / \mathbf{c m}^{3}\right]}\end{array}$ & $\begin{array}{c}\text { Compressive strength } \\
{\left[\mathbf{N} / \mathbf{m m}^{2}\right]}\end{array}$ & $\begin{array}{c}\text { Carbonation } \\
\text { depth [mm] }\end{array}$ \\
\hline K1 & Ceiling, block 14, south tube & 2.238 & 36.5 & $15-20$ \\
\hline K2 & Wall, block 14, south tube & 2.242 & 40.9 & 0 \\
\hline \multicolumn{2}{|c|}{ Mean value of south tube } & 2.240 & 38.7 & - \\
\hline K3 & Ceiling, block 40, north tube & 2.276 & 58.8 & 10 \\
\hline K4 & Wall, block 40, north tube & 2.376 & 60.2 & -10 \\
\hline \multicolumn{2}{|r|}{ Mean value of north tube } & 2.326 & 59.5 & - \\
\hline
\end{tabular}

Table 2. Concrete covers.

\begin{tabular}{|c|l|l|}
\hline Specimen & Sample removal area & Concrete cover \\
\hline K1 & Ceiling, block 14, south tube & $44 \mathrm{~mm}$ \\
\hline K2 & Wall, block 14, south tube & $55 \mathrm{~mm}(+$ tile and mortar totally $95 \mathrm{~mm})$ \\
\hline K3 & Ceiling, block 40, north tube & $65 \mathrm{~mm}$, reinforcing mesh $=23 \mathrm{~mm}$ \\
\hline K4 & Wall, block 40, north tube & $65 \mathrm{~mm}$, reinforcing mesh $=23 \mathrm{~mm}$ \\
\hline
\end{tabular}

\subsection{Concrete cover}

The concrete cover has been directly measured on the core. The results are listed in the following Table 2.

\subsection{Thermal analysis}

To get information concerning the mineralogical composition and the moisture content of the concretes thermal analyses have been performed with a material sample taken about $2 \mathrm{~cm}$ below the outer front face of the cores. The results revealed, that both types of concretes are made with normal Portland cement and siliceous aggregates. The moisture content respectively the physical bound water liberated up to $150{ }^{\circ} \mathrm{C}$ was 3.0 mass- $\%$ in $\mathrm{K} 1$ and 4.1 mass- $\%$ in $\mathrm{K} 4$.

\subsection{Mercury porosimetry}

Besides the strength and moisture content the density of the concrete determines the sensitivity for explosive spalling during fire exposure [9, 10]. Therefore the density of the concretes has been determined by aid of mercury porosimetry. The investigations have shown, that both concretes have a gel porosity of the same order of magnitude (about 3.1 vol.- $\%$ ), and that the concrete of the southern tube has a significantly higher porosity in the capillary pore region (between $10 \mu \mathrm{m}$ and $0.03 \mu \mathrm{m}$ ) than the concrete of the younger northern tube. The capillary porosity of the older concrete was 8.6 vol.- $\%$ and that of the younger concrete was 4.5 vol.- $\%$. With a total porosity of 10 vol.- $\%$ the younger concrete has a much higher density than the older concrete (total volume 14.5 vol.- $\%$ ).

\subsection{Investigation and results of the fire protection board}

A part of the plate which has been taken away for the drilling of the K1 has been investigated with regard to compressive and bending tensile strength, moisture content, mineral composition etc. The results indicated, that the material (typical calcium silicate board), which has been installed in the year 2000, has not suffered any deterioration due to moisture, frost action, mechanical stress or others and got no strength loss. 


\section{DEMANDS ON THE FIRE PROTECTION ACCORDING TO THE RABT}

According to the actual German rules and guidelines (RABT [1] or ZTV-ING, part 5 tunnel construction [2]) the construction have to be built in such a way, that in case of fire:

- no damages occur, which endanger the structural stability,

- no residual deformations of the construction arise, which may reduce the usability

- the tightness (against ground water) remains intact.

The cited guidelines are also applicable for the upgrading of the existing traffic tunnels if - after examination of the proportionality of the measures to be taken - possible and reasonable ([2], Kap. 0, Introduction). The consideration of the thermal effects shall be based on the so called RABT-fire curve. According to this temperature-time-curve the temperature in the fire compartment rises within 5 min from ambient temperature to $1200^{\circ} \mathrm{C}$, stays there for $25 \mathrm{~min}$ and sinks linearly with time within $110 \mathrm{~min}$ down to room temperature. French and Swedish investigations have been based on similar time-temperatures curves [3-5].

The demanded fire protection (according to [1] and [2]) can be reached by compliance of constructional minimal requirements, for example by protecting the bearing reinforcement against heat up-to more than $300^{\circ} \mathrm{C}$. Usually this can be reached with a sufficient minimal concrete cover, which remains in place during the whole fire attack.

According to ZTV-ING, part 5, section 2 [2], for the adherence of the concrete cover in case of fire a reinforcing mesh (N94) with a concrete cover of $20 \mathrm{~mm}$ has to be placed (as visible in Fig. 4). For the walls this measure can be left out, because the load bearing reinforcement is located on the opposite face of the fire attack near the outer surface. For the construction under consideration the minimum cover for the load bearing reinforcement shall be $6.0 \mathrm{~cm}$. Under this condition, in case of fire the maximum temperature in the axis of the reinforcement would remain below $300{ }^{\circ} \mathrm{C}$.

Admittedly, the effectiveness of the mesh reinforcement for the protection against spalling has been not established yet, respectively it is ineffective with high strength concrete members. The latter has been observed and reported many times $[9,10]$.

\section{REMARKS CONCERNING SPALLING OF CONCRETE EXPOSED}

Usually with spalling of concrete exposed to fire a distinction is made between aggregate spalling, explosive or destructive spalling, sloughing off and others. These phenomena have been widely investigated [11-14]. Most often destructive spalling occurs (Fig. 5). It is explained with thermohydraulic processes $[10,11]$. According to Meyer-Ottens and others $[12,13]$ the spalling is not to be expected if the moisture content of the concrete is less than 2.5 mass- $\%$ in case of fire exposure according to the ISO-834-fire curve.

Investigations of existing tunnels have shown that the above-mentioned moisture content is usually exceeded. Already in $3 \mathrm{~cm}$ depth the concrete moisture levels are higher than 3 mass-\%. Therefor the spalling is to be expected in case of fire in the tunnel [14].

Accordingly, for the occurrence of high pore pressures (vapour pressure) and therefor for the spalling in addition to the water content also the tightness of the concrete and the rate of temperature rise are decisive. In [10] as a critical temperature rise for an unprotected concrete surface $70 \mathrm{~K} / \mathrm{min}$ is given. Above this heating rate the probability of spalling is classified as very high.

\section{EVALUATION OF THE TUNNEL'S FIRE SAFETY}

\subsection{Evaluation of the southern tube}

In the southern tunnel the rebars in the sidewalls are protected against the direct fire attack by the $55 \mathrm{~mm}$ thick concrete cover and additionally by $10 \mathrm{~mm}$ thick tiles plus approx. $30 \mathrm{~mm}$ thick mortar layer 


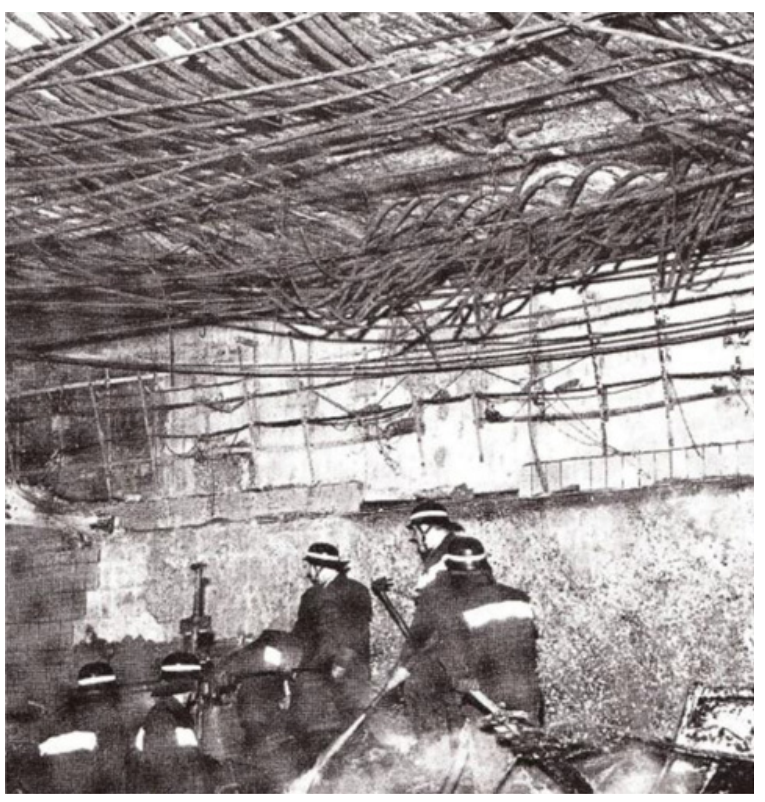

Figure 5. Severe damages after a fire in the Hamburg-Moorfleet-tunnel with explosive spalling of the concrete cover followed by plastic deformation of the rebars at the ceiling (after [13], p. 20).

(Table 2). The total coverage of the reinforcing steel is around $95 \mathrm{~mm}$. As shown by the calculations of the temperatures during the thermal exposure according to the RABT-fire-curve (Fig. 6), the $300{ }^{\circ} \mathrm{C}$ isotherm, which migrates $6.8 \mathrm{~cm}$ into the concrete, would not reach the reinforcement (compare Fig. 6c).

In the ceiling, the concrete cover of the load bearing reinforcement is approx. $50 \mathrm{~mm}$ (Table 2). The concrete surface is protected against direct flame attack by the $\mathrm{d}=2 \mathrm{~cm}$ thick fire-resistant calcium silicate board (with a thermal conductivity $\lambda=0.212 \mathrm{~W} / \mathrm{mK}$ ). The temperature at the surface of the concrete increases with a maximum speed of $10 \mathrm{~K} / \mathrm{min}$ and reaches about $260^{\circ} \mathrm{C}$ after 50 min (see Fig. 7a). The $300^{\circ} \mathrm{C}$-isotherm remains most of the time within the fire protection board (Fig. 7c). The first time it penetrates $0.2 \mathrm{~cm}$ deep into the concrete after 1 hour of fire exposure. The $5.0 \mathrm{~cm}$ covered reinforcement (distance of the axis of the bar to the concrete surface is about $6 \mathrm{~cm}$ ) reaches its maximum value of $125^{\circ} \mathrm{C}$ after $2 \mathrm{~h}$ (Fig. 7a).

Due to the low heating rate at the surface of the concrete $(<10 \mathrm{~K} / \mathrm{min}$ which is significantly less than the critical rise of $70 \mathrm{~K} / \mathrm{min}$ ), and the relatively high volume of its capillary pores spalling reactions are excluded. i.e., the ceilings and the upper parts of the walls which are provided with fire protection boards also satisfy the requirements of the current RABT [1] respectively ZTV-ING [2].

\subsection{Evaluation of the northern tube}

In the side walls the load bearing rebars are protected by a $65 \mathrm{~mm}$ thick concrete cover from direct fire attack. Additionally, to prevent the spalling and subsequent direct exposure of rebars to the flames, a reinforcement mesh has been placed (Table 2).

In the ceilings of the northern tunnel the concrete cover of the rebars is around $65 \mathrm{~mm}$ (Table 3). As indicated by the temperature calculation (Figs. 6 and 7), the temperatures on the surface rise within the first 5 minutes at a rate of $240 \mathrm{~K} / \mathrm{min}$; in $1 \mathrm{~cm}$ concrete depth with about $100 \mathrm{~K} / \mathrm{min}$. 

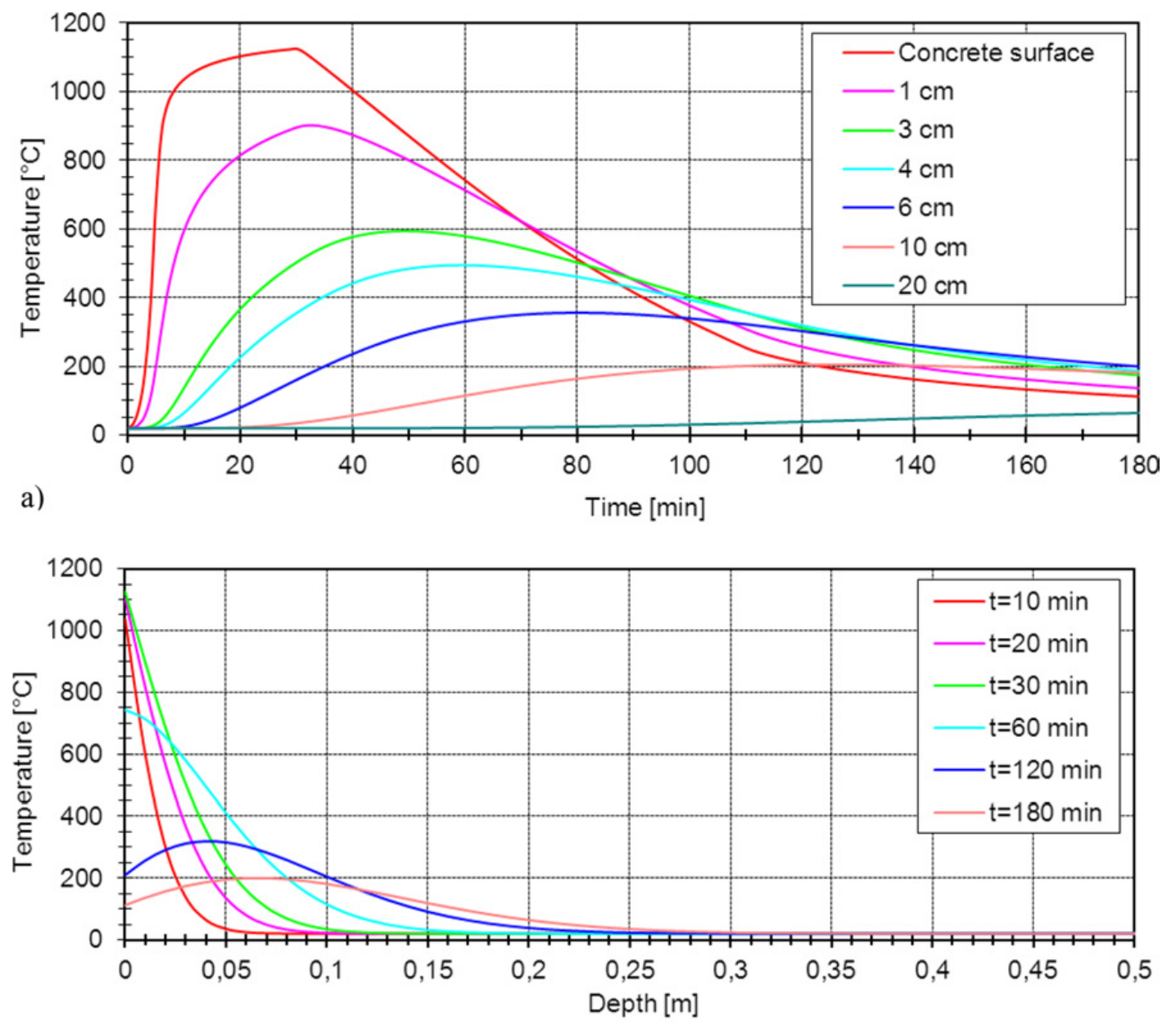

b)

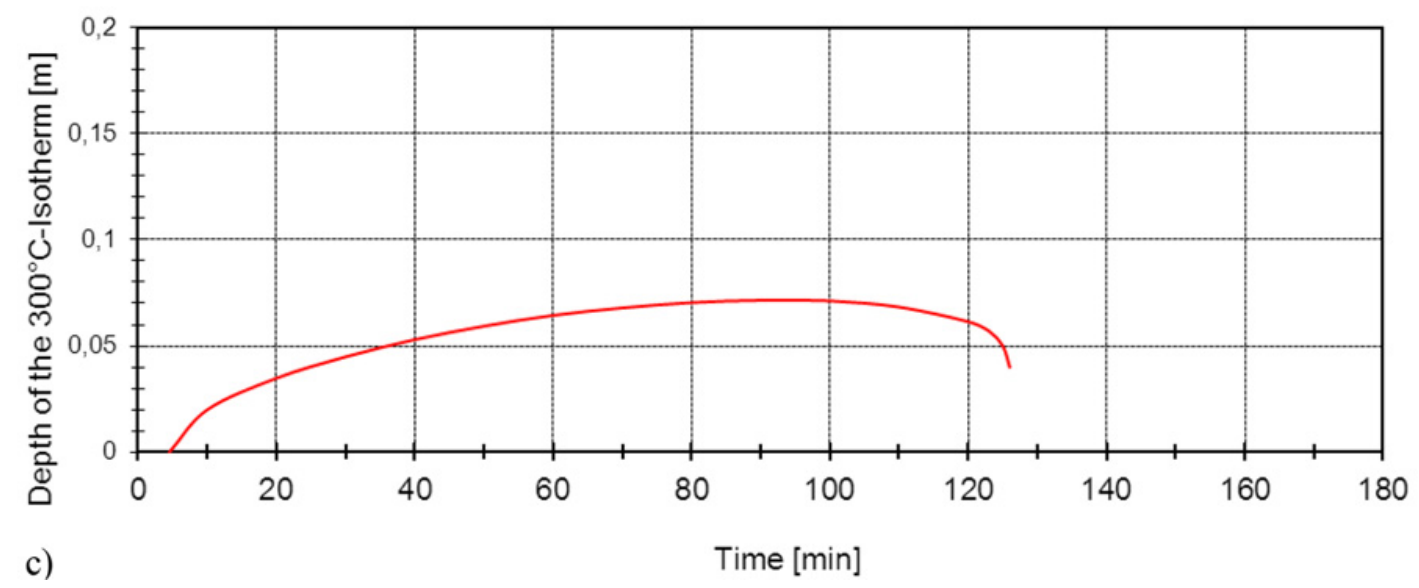

Figure 6. Temperature development on the surface and inside the unprotected reinforced concrete slab while exposure to a fire according to the RABT-fire curve (a), temperature distribution versus depth (b) and run of the $300{ }^{\circ} \mathrm{C}$ - isotherm (c). 
MATEC Web of Conferences
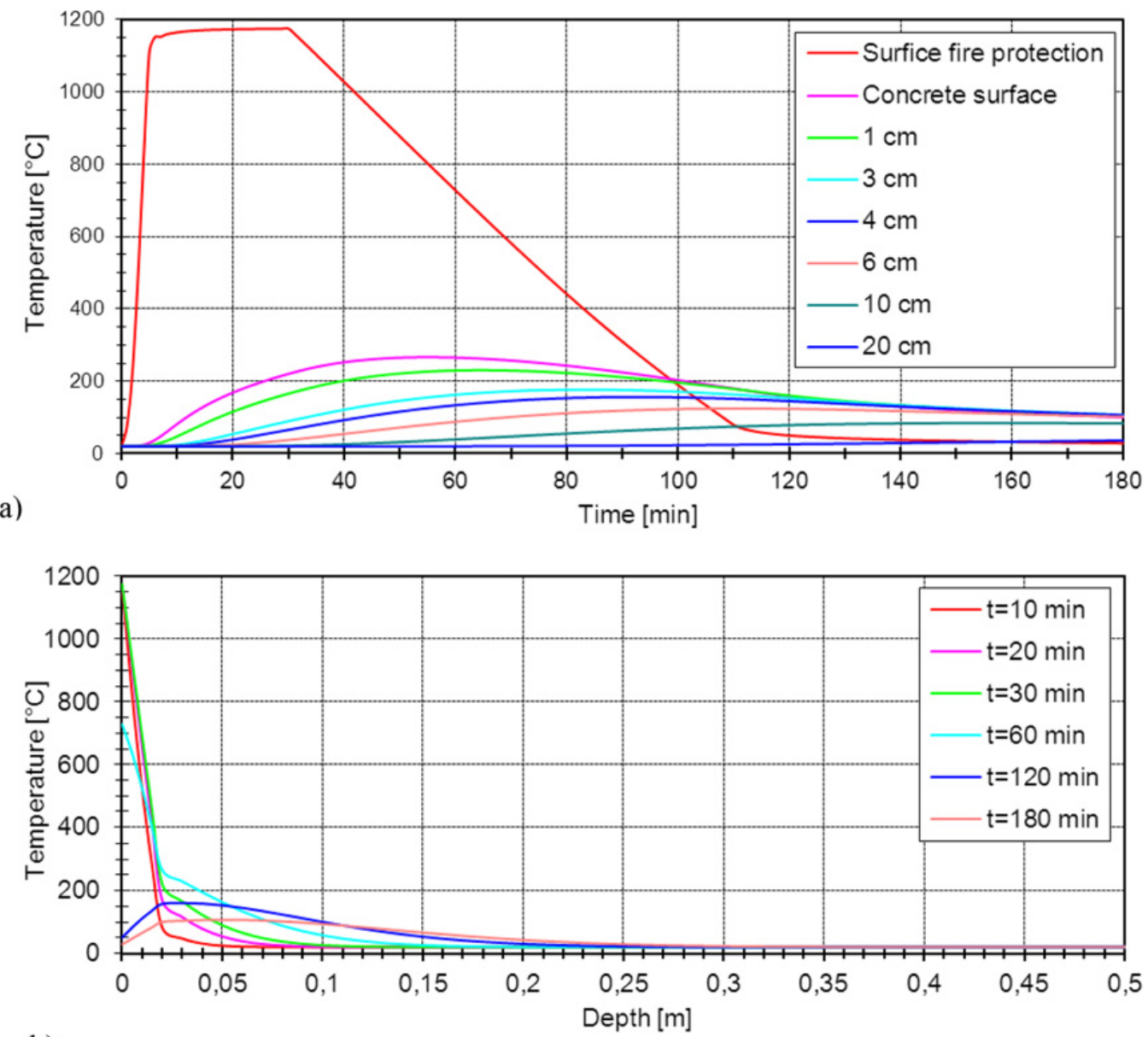

b)

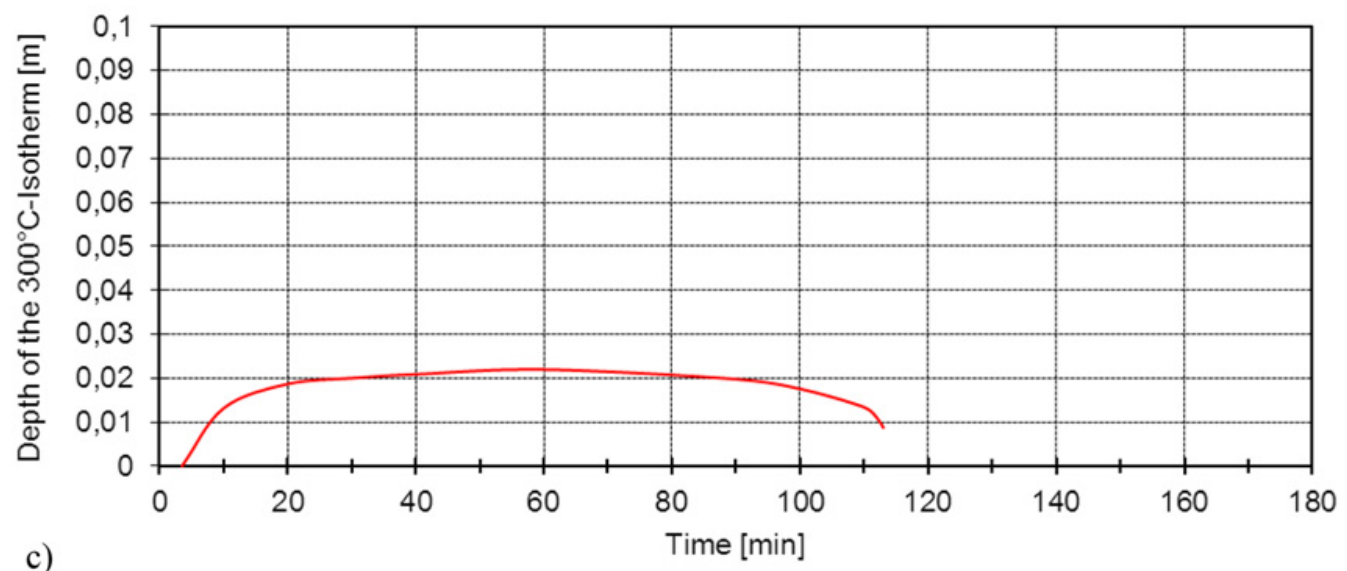

Figure 7. Temperature development on the surface and in the reinforced concrete slab, protected with a $20 \mathrm{~mm}$ thick calcium silicate board (with $\lambda=0.212 \mathrm{~W} / \mathrm{mK}$ ) while exposure to a fire according to the RABT-fire-curve (a), temperature distribution versus depth (b) and run of the $300^{\circ} \mathrm{C}$-isotherm (c). 
In $6 \mathrm{~cm}$ depth, which is even under the $65 \mathrm{~mm}$ rebar cover (Ø $16 \mathrm{~mm}$ ), after approx. 60 minutes nearly $300^{\circ} \mathrm{C}$ is reached. After 90 minutes the reinforcement remains just below $300^{\circ} \mathrm{C}$ with its centre distance of $73 \mathrm{~mm}$. The influence of fire remains limited to a component depth of $25 \mathrm{~cm}$. Without occurrence of concrete spalling the temperature rises in the said depth within 180 minutes to about $60^{\circ} \mathrm{C}$. The $300^{\circ} \mathrm{C}$ isotherm reaches up to $7 \mathrm{~cm}$ deep into the concrete. i.e., the concrete reinforcement covered with $65 \mathrm{~mm}$ (distance to the centre axis to the surface $=73 \mathrm{~mm}$ ) remains below $300^{\circ} \mathrm{C}$.

However, according to the thermal analysis the concrete in the ceiling has a humidity of at least 3.5 mass-\% (see 3.5 Thermal analysis). It also has a very high density, such as the porosity measurements have shown. Also, the heating rates would exceed by $240 \mathrm{~K} / \mathrm{min}$ at the surface and by $100 \mathrm{~K} / \mathrm{min}$ in $1 \mathrm{~cm}$ depth the limit for the occurrence of spalling which is $70 \mathrm{~K} / \mathrm{min}$. In other words, the risk of spalling is very high for the reinforced concrete ceiling. - According to calculations of U. Schneider \& M. Schneider [15] in the lower parts of the side walls the temperature rise and the maximum temperatures are much lower than on the wall crowns and ceilings. They are so low that spalling is unlikely to occur in the lower side wall areas. This is also in accordance with observations made during real fires like in the Moorfleet-Tunnel (compare Fig. 5).

Schneider and Horvath $[14,16]$ reported on tests of inner shells of a tunnel under fire exposure in accordance with the so-called EBM-fire-curve, which corresponds concerning temperature increase rate and maximum temperature with the RABT-fire-curve. They observed for a typical concrete humidity of 3 mass-\% after 36-minute fire exposure spalling depths of $8 \mathrm{~cm}$. After said exposure time the spalling reactions sounded again.

Some deeper spalling occurred during the fire in Hamburg-Moorfleet-tunnel in 1968 (Fig. 5, [13], pp. 200). However, the respective fire of a lorry carrying 14 tons of polyethylene was an extremely unfavourable case, in which also a maximum temperature of $1200^{\circ} \mathrm{C}$ has occurred ([13], p. 396).

Spalling depth as reported by Horvath et al. [16] has been observed also after a car fire under a bridge over the highway near Schleswig in Germany [17]. Here a maximum spalling depth of $5.6 \mathrm{~cm}$ occurred.

From these facts it can be concluded, that due to the high probability of spalling the tunnel should receive a fire-safety retrofitting of the reinforced concrete ceilings and upper parts of the side walls to meet the basic requirements of the current ZTV-ING [2] and RABT [1], but above all, to keep in case of fire the damage of the structure, and in turn, the air traffic and the road traffic-related disturbances, disruptions and impairments in the vicinity of the tunnel as low as possible.

\section{FIRE SAFETY UPGRADING OF THE NORTHERN TUNNEL}

Due to the rapid heating rates and high temperatures during a tunnel fire (Fig. 6), the concrete surfaces of the ceiling and about $1.0 \mathrm{~m}$ high crown areas of the side walls of the northern tunnel should be protected from the effects of direct fire exposure. For this, fire protection systems in the form of plasters or sheet cladding are available in the market $[9,10,18,19]$. But also new materials, like aluminosilicate-based coatings are ready for use in practice [20].

By the installation of fire protection boards or plasters (with comparable thermal and mechanical characteristics), the temperature rise on the concrete surface can be limited to about $260^{\circ} \mathrm{C}$ (Fig. 7). The rate of temperature rise at the concrete surface will be reduced to approx. $6 \mathrm{~K} / \mathrm{min}$, which reduces the risk of spalling practically to zero. The 50 to $65 \mathrm{~mm}$ covered rebars are heated to a maximum of $120^{\circ} \mathrm{C}$. These temperatures are well below the ZTV-ING [2] or the RABT [1] specified critical temperature of $300^{\circ} \mathrm{C}$.

Investigations at CSTB [18] have indicated that the application of the fire protection materials needs a careful design, planning and execution. Improper selection of materials thickness may lead to insufficient thermal protection. In such arrangements spalling occurred during heating (according to the hydrocarbon fire) and the concrete spalling was even deeper than with slabs with no protection. 


\section{MATEC Web of Conferences}

\section{CONCLUSION}

As an example, the fire safety evaluation of a traffic tunnel in a larger city of Northern Germany has been conducted. The tunnel is situated below the runaway of an airport. It consists of two tubes. The older southern tube was erected in 1963 and the newer, northern tube in 1997. In the former tunnel the side wall concrete surfaces are protected from direct exposure of the fire by tiles and mortar and the ceiling by calcium silicate boards. The walls and ceilings of the newer tube have been erected as exposed concrete structures without any fire protection lining.

Throughout the study visual inspections, sampling and investigations of concrete cores and fire protection lining as well as calculations of the temperature fields during a fire have been performed according to the so called RABT-fire-curve.

Because the concrete surfaces of the ceilings and the walls of the southern tube are protected by an intact calcium silicate fire protection board, the heating rates are so low, that spalling of the concrete cover is rather unlikely to occur. By the fire protection boards also the penetration of the $300{ }^{\circ} \mathrm{C}$-isotherm into the concrete is limited in a such way that the reinforcement remains below the acceptable limit of $300^{\circ} \mathrm{C}$.

The concrete of the newer, northern tunnel is much denser and has a significant higher strength than the concrete of the older tube.

Due to the high strength of the concrete (which amounts to concrete class C65/60), the high moisture content and the rapid heat up of the unprotected concrete surface for the ceilings and the upper parts of the walls an extremely severe risk of destructive spalling exists. In such case the reinforcement could be heated to very high temperature and could lose its strength to such extend, that the load bearing capacity of the whole tunnel can fall below the acceptable limit. In turn the runway and the tunnel had to be closed until the termination of the rehabilitation of the tube, causing unacceptable traffic disruptions and impairments.

By the installation of fire protection boards or plasters available in the market the temperature rise of the concrete surface could be limited to such an extent that spalling can no longer occur and the maximum temperature of the reinforcement remains below $300^{\circ} \mathrm{C}$, which is the limit value according to the currently valid rules.

The paper was published thanks to financial contribution of the project SUPMAT - Promotion of further education of research workers from advance building material centre. Registration number: CZ.1.07/2.3.00/20.0111, funded by European Social Funds, Operational program Education for Competitiveness and also project GAČR P104/12/1988 Study of interaction of components of cementious composits exposed to high temperatures.

\section{References}

[1] RABT 1004: Richtlinien für die Ausstattung und den Betrieb von Straßentunneln. Forschungsgesellschaft für das Straßenwesen, Köln, 2006.

[2] ZTV-ING: Zusätzliche technische Vertragsbedingungen und Richtlinien für Ingenieur-bauten, Teil 5 Tunnelbau, Abschnitt 1, geschlossene Bauweise, Kap. 10, Verkehrsblatt-Sammlung Nr. S. 1056, Stand 1/03.

[3] Ministére de l'Equipement (2000) Instruction technique annexée á la Circulaire intermini-stérielle no 2000-63 du 25 Aout 2000 relative á la sé curité dans les tunnels du réseau routier francais. Bulletin officiel du Ministére de l'Equipement nº 20000-6 du 0109 2000, Paris.

[4] Taillefer, N., Carlotti, P., Lemerle, CH., Avenel, R., Larive, C., Pimienta, P. Ten years of increased hydrocarbon temperature curves in French Tunnels, Fire Technology, 49 (2), 531-549, 2013. 
[5] Bostrom, L., Larsen, C.K. Concrete for tunnel linings exposed to severe fire exposure, Fire Technology, 42 (4), 351-362, 2006.

[6] Bodnárová, L., Zach, J., Hroudová, J., Válek, J. Development of Concretes with Resistance to High Temperatures in the Czech Republic and Surrounding European Countries, Advanced Materials Research, 651, p. 120 - 125, 2013.

[7] Herka, P. Fire resistance of tunnel lining, Czech Tunnelling Association ITA-AITES, 2013.

[8] Rostásy, F.S., Baustoffe, Verlag W. Kohlhammer, Stuttgart. Berlin. Köln Mainz, 201, 1983.

[9] Diederichs, U., Jumppanen, U.-M., Schneider, U. High Temperature Properties and Spalling Behaviour of High Strength Concrete, Proceedings of the Fourth Weimar Workshop on High Performance Concrete: Material Properties and Design, Witmman, F.H. Schwesinger, P. (Hrsg.), AEDIFICATIO Verlag GmbH, Freiburg i. Br. \& Unterengstringen (CH), Weimar, Germany, 4/105/10, 1995.

[10] Richter, E., Schnetgöke, R. Brandschutzvorschriften für Straßentunnel in den neuen ZTVING, Teil 5, Praxisseminar 2004 Brandschutz bei Sonderbauten, September 2004, Kurzreferate, Heft 178 der Schriftenreihe des Instituts für Baustoffe, Massivbau und Brandschutz, TU Braunschweig, September 2004.

[11] Schneider, U., Horvath, J. Brandschutzpraxis in Tunnelbauten, Bauwerk-Verlag, Berlin, 2006.

[12] Kordina, K., Meyer-Ottens, C. Beton-Brandschutz-Handbuch, Beton-Verlag GmbH, Düsseldorf, 1981.

[13] Kordina, K., Meyer-Ottens, C. Beton-Brandschutz-Handbuch - 2. Auflage, Verlag Bau + Technik GmbH, Düsseldorf, 1999.

[14] Schneider, U., Horvath, J. Abplatzverhalten an Tunnelinnenschalenbeton. Beton\&Stahlbetonbau, 97, 2002.

[15] Schneider, M., Schneider, U. Calculation of temperature development on concrete members during tunnel fires by CFD modelling. In Zigoni (Ed.): Advances and Trends in Structure Engineering, Mechanics and Computation, Taylor and Francis Group, London, 2010.

[16] Horvath, J., Schneider, U., Diederichs, U. Beiträge zum Brandverhalten von Hochleistungsbetonen. Institut für Baustofflehre, Bauphysik und Brandschutz, TU Wien, 2003.

[17] Diederichs, U., Hein, S. Gutachtliche Stellungnahme zu den Auswirkungen der Schäden des Brandes vom 19.08.2003 an der Überbauuntersicht der Brücke über die BAB A7 bei Jagel, Nr. G 030044 -Die/Hei-, Rostock, 17.09.2003.

[18] Pimienta, P., Octavian, A., Mindeguia, J. CH., Avenel, R., Cuypers, H., Cesmat, E. Fire protection of concrete structures exposed to Fast Fires, Fourth International Symposium on Tunnel Safety and Security, Frankfurt am Main, Germany, 17/03-19/03, 2010.

[19] Vejmelkova, E., Konvalinka, P., Padevet, P., Cerny, R., Effect of high temperatures on mechanical and thermal properties of carbon-fiber reinforced cement composite, CEMENT WAPNO BETON, 13 (2), pp. 66, 2008.

[20] Krivenko, P., Pushkareva, Y. K., Sukhanevich, M. V., Guziy, S. G. Fireproof coatings on the basis of alkaline aluminum silicate systems, Editor(s): Lin, H. T., Koumoto, K., Kriven, W. M., Garcia, E., Reimanis, I .E., Norton, D. P., Ohji, T., Wereszczak, A., Developments in strategic materials. Book series: Ceramic engineering and science proceedings, 29 (10), 129-142, 2009. 